\title{
The Role of Education Quality Management in Improving Qur'any Literacy Culture
}

\author{
Tin Sukaisih \\ Sekolah Islam Miftahul Ulum Makarti Jaya \\ e-mail: tiensukaisih44@gmail.com \\ Tri Widayatsih \\ Universitas PGRI Palembang \\ e-mail: triwidayatsih@univpgri-palembang.ac.id \\ Yessi Fitriani \\ Universitas PGRI Palembang \\ e-mail: yessifitriani@univpgri-palembang.ac.id \\ Article History: Received on 15 November 2021, Revised on 30 December 2021 \\ Published on 18 January 2022
}

\begin{abstract}
The importance of education quality management in improving the culture of qur'any literacy at Miftahul Ulum Makarti Jaya Islamic School is described in this qualitative research. According to the study's findings, education quality management has a role in producing superior output generation that is inventive, critical, leadership, and creative superior and able to compete well and have more value in religious abilities. Being cultural and literate, as well as critical thinking, are two qualities that can develop outputs that are ready to participate in society.
\end{abstract}

Keywords: Education Quality Management, Literacy Culture, Qur'any, Islamic Schools

\section{A. Introduction}

The prevailing perspective of a nation's education program is that the better the education of a nation, the greater the quality of the nation itself (Zein et al., 2021). A robust quality management system is also required for a good school. Education as a pillar entrusted with developing character and achievement in human resources. Efforts to increase education quality remain the top priority in development (Syarifuddin et al., 2021). Cultural literacy is one of the high-quality education programs. Because promoting literacy in schools would ensure that future generations of the nation retain information and obtain various types of insights. Principals, instructors, education staff, stakeholders, and students are all significant components of schools as institutions. A quality management of school education to accomplish the aim that depends on the spirit of collaboration and habituation of mutual need in the success of the school program, specifically between administrators, teachers, education staff, and students in carrying out their respective roles.

The early history of the creation of the literacy tradition in Islam may be traced back to the time of the Prophet Muhammad SAW, with Usman Bin Affan's process of gathering and writing the Koran to serve as an universal reference document. Even if the writing procedure could not have been faultless at the time since revelation continued to trickle down with the 
Volume 2 (3) 2021

E-ISSN: 2723-6919 P-ISSN: 2746-0827

rules and stories of the ancestors. The revealed words of the Qur'an have been written in numerous mediums from the time of the Prophet Muhammad SAW, including papyrus (Majid, 2019). Literacy in Qur'anic dimensions is a duty from Allah and His Messenger. Divine literacy can be characterized as literacy that is God's command. Divine literacy is associated with reading commandments, as well as reading letters, numbers, and the universe (Majid, 2019). Literacy, which is the prophet's command, is writing, which might be characterized as prophetic literacy.

Literacy culture is an excellent source of creative writing and reading for all members of society, particularly students. Literacy is one of the Miftahul Ulum school's signature projects. It becomes a comprehension of what is regarded to be the basis of acquired knowledge, not just being able to read and write practically, but objectively based on history and philosophy, in the building of thinking from literacy culture. Today's youngsters benefit greatly from the simplicity of acquiring knowledge via numerous digital means. Through adaptation to global changes, the routine of reading, writing, and researching the contents of the Qur'an forms a proportionate and continuous structure of literate cultural items. Al-Alaq verses 1-5, Al-Qalam verse 1, Al-Kahfi 109, Al-Baqarah verses 78-79, Al-Ankabur verses 48-49, and Al-Baqarah verse 282 are among the verses that carry the message of literacy. There are three expressions in the Qur'an that show the meaning of reading: Al-Qira'ah, recitation, and tartil. Some passages of the Qur'an, such as Al-Alaq's first verse, Al-Jumu'ah, and Al-Muzammil's fourth verse are translated as "recitation."

Reinforced by research conducted by (Majid, 2019), in his research journal on "quality culture management in improving the quality of education in primary schools," he explains that an ideal quality improvement and expansion of education must include several indicators such as 1) the adequacy of educational resources in terms of the quality of education personnel, costs, and learning facilities, 2) the quality of the teaching and learning process that encourages students to learn effectively, and 3) the quality of the learning environment. Quality is defined as compliance to specifications; for example, a product is considered to be of good quality when it meets the agreed-upon standard objective (Laksono, 2021).

The Covid-19 epidemic is one among the factors causing education to change its face and course. It has also shifted from the learning process to the new curriculum, becoming the New Paradigm curriculum or the Prototype curriculum as a supplement to the old curriculum, particularly KTSP and K13. Begin driving schools, and the government picks instructors to gradually relocate schools. In practice, this greatly promotes the literacy culture initiative in schools. The Qur'any literacy culture program, which is conducted by the Miftahul Ulum Islamic school. It is critical to express the description of the curriculum's new paradigm. The new paradigm of 2022 curriculum includes seven new things: first, the framework of the curriculum, the Pancasila student profile as a reference in Learning Outcomes. Second, employing Learning Outcomes, which are a collection of knowledge, abilities, and attitudes, as a single ongoing process to develop total competence. Third, the application of the learning process with a thematic approach, which was previously only permitted at the primary school level, is now permitted at all levels of education under the new curriculum. Fourth, the number of lesson hours per year is fixed so that each school can easily manage the implementation of its learning activities. Fifth, schools are allowed the latitude to implement collaborative learning models across topics and to conduct cross-subject assessments, such as summative evaluations in the form of projects or project-based assessments. Sixth, the inclusion of ICT or Informatics topics at all levels, beginning with SMP/MTs and progressing to SMA/MA/SMK. 
Volume 2 (3) 2021

E-ISSN: 2723-6919 P-ISSN: 2746-0827

Seventh, the integration of topics such as science/IPS, which was once split into one, is known as IPAS, and majors in science, social studies, and language at the high school or Aliyah level are discontinued in class X but retained in classes XI and XII.

Education quality management plays a critical role in strengthening the Qur'any literacy culture in schools. Literacy in schools and independent literacy are both beneficial types of engagement. Writing and reading as educational literacy have become increasingly important as times and technology improvements have made it necessary for every human being to practice writing and reading skills, according to (Sukaisih et al., 2021) writing and reading are topics that all people are taught from the time they begin school. Students are taught to read and then write down what they read. Based on (Fitriani, 2018) writing is an activity that is both productive and expressive. Writing abilities do not come naturally; they must be acquired via a lot of practice and on a regular basis. Writing, he says again, is an expression of one's thoughts that promotes two-way communication, namely between the writer and the reader (giver and recipient). We may understand other people's opinions through reading their works. According to Fahmi (2014) and (Sukaisih et al., 2021) writing is a method for the outpouring of thoughts, concepts, or information that is written with the right structure, has strong coherence across paragraphs, and is devoid of mechanical faults such as spelling and grammar. Reading ability may be enhanced by using the proper approach (Fadhli, 2020). As a result, the Indonesian government began a school literacy movement initiative under the Ministry of Education and Culture of the Republic of Indonesia. This movement attempts to strengthen the literacy culture in order to develop the character that exists in the individual, namely for students and instructors in the educational institution.

This study was carried out at Miftahul Ulum Makarti Jaya Islamic School. Researchers discovered indicators indicating that the Miftahul Ulum Islamic school experienced a significant decline in the number of students due to the community's lack of interest in studying the Qur'anic literacy process based on initial observations made by researchers on August 15, 2021, until August 25, 2021. According to the findings, this situation was created by a lack of schools in the process of effectively managing institutions in terms of innovation in quality management activities for education in the field of literacy culture as a whole. As a result, passion for the learning process decreases. According to the findings of the researcher's observations, the difficulty of instructors in managing or applying the culture of Qur'any literacy was due to a shortage of teachers who were specialists in the field of learning Qur'an knowledge. Teachers and schools have simply established and altered general learning demands in line with curriculum 13 and the features of pupils at the Miftahul Ulum Islamic school, who are less creative in promoting qur'any literacy in schools. The issue is that instructors' capacity to master the knowledge of the Qur'an is restricted, thus the Qur'any literacy culture program is less of a priority in the process of civilizing Qur'any literacy at the Miftahul Ulum Makarti Jaya Islamic school.

Furthermore, there is no distinct training program connected to the culture of qurany literacy in which all instructors engage, which is why teachers have not been able to properly apply the program to develop the culture of qurany literacy at the Miftahul Ulum Makarti Jaya Islamic school. Some instructors are still uninterested in literacy, owing to a lack of imagination in creating literacy from other topic areas taught in schools. Simply attend class, take notes, explain, and complete. There is no desire to further enhance the subject's substance by relating it to literacy and creativity in the form of real job. Researchers believe that the learning process in schools is associated with quality management of education in improving the culture of 
Volume 2 (3) 2021

E-ISSN: 2723-6919 P-ISSN: 2746-0827

qur'any literacy where only some teachers are experts in the field of qur'an who facilitate qur'any literacy for students, because other teachers are graduates of public schools, then the Qur'any literacy culture program that the school principal initiated is less than optimal in its implementation.

Miftahul Ulum Makarti Jaya Islamic School has saw a large drop in student enrollment during the COVID-19 epidemic. As a result, it has an impact on the learning process in terms of both the number of students and instructors who are actively involved in the learning process, as well as the quantity of finances, which has been dramatically cut compared to the previous three years. This circumstance has a significant impact on the accreditation value, which was originally assigned "B", because the number of students who did not satisfy the requirement was assigned " $\mathrm{C}$ ". Thanks to God, the school continues to operate as normal and is becoming even more excited in pursuing the backward aim as a result of numerous difficulties now confronting the miftahul ulum Islamic school. As a result, the school is trying hard to recover by developing a variety of exceptional learning programs based on the Qur'any literacy culture. With these eight criteria, the school is attempting to increase the quality of instruction while also fostering a culture of Quranic literacy at the Miftahul Ulum Makarti Jaya Islamic school.

Learning is defined as the delivery of knowledge and activities that assist or assist students in achieving the intended learning objectives. It is vital to focus on pupils in order for an effective learning process to occur. Learner-centered learning is not teacher-centered, and knowledge is viewed as a social construct that can be improved through peer interaction, assessing learning activities, and collaboration in working on and succeeding in the Qur'any literacy culture program at the Miftahul Ulum Makarti Jaya Islamic school.

As a result of the researchers' observations, it is possible to conclude that the implementation of the Qur'any literacy culture is still limited to the implementation of limited learning administration and for specific students only due to the limited number of teachers involved in the Qur'any literacy culture program. In other words, the implementation of the Qur'anic literacy culture at the Miftahul Ulum Islamic school has not been controlled in line with the quality of education. Because of the shortage of human resources for instructors and personnel who do not satisfy the standards for Qur'anic material competence, the flagship program of the Qur'anic literacy culture is limited in its progress and development for students as a whole. As a result, the school's product is less appealing to the surrounding population. Aside from the weakening of educators' spirits and the failure to carry out the tasks of literacy culture as a profession in every topic relevant to qur'any literacy.

According to preliminary observations, the principal of the aliyah school, Miftahul Ulum Makarti Jaya, has directed that all teachers participate in literacy training at online institutions widely available on social media such as Facebook, Instagram, Google, and so on, which even tend to be training in nature, certificate for free. However, the researcher believes that there are many tendencies that make teachers' interest in being drivers of qur'any literacy culture less desirable in learning more about how to properly literate students in accordance with the qur'any literacy culture programs initiated by the principal of the Islamic school Miftahul Ulum Makarti Jaya. There are only two instructors who are frequently assigned to attend online seminars or literacy activities that are class programs until the teacher can create a written work and take classes in teaching the Qur'an using the Protaba and Al-Husna methods. By composing and reading Qur'anic manuscripts every day, it is believed that it would become a driving force in the Qur'any literacy culture initiative in the future. As a result, a strategy for the role of 
Volume 2 (3) 2021

E-ISSN: 2723-6919 P-ISSN: 2746-0827

education quality management in improving the culture of qur'any literacy, which refers to eight national education standards, is required, as school principals must be even more enthusiastic in supporting teachers and stakeholders of the miftahul ulum Islamic school so that the qur'any literacy culture program can be implemented.

The above explanation concludes that teachers and employees at the Islamic school Miftahul Ulum Makarti Jaya do not fully understand and know about the Qur'any Literacy Culture, so based on the above background, the author attempts to examine and discover how the role of the principal in managing the quality of the school's education in improving the Qur'any Literacy Culture through the performance of teachers and employees as quality management of education as $t$ As a result, the writers are curious about a study named The Role of Education Quality Management in Improving Qur'any Literacy Culture at Miftahul Ulum Makarti Jaya Islamic School.

According to research results from the Research and Development Center for Lectures and Religious Khazanah (2016), the Al-Qur'an literacy index among high school students throughout Indonesia remains in the medium and low ranges, particularly for aspects of reading (2.59), writing (2.2), and interpreting (1.87) on a scale of 1-5. These findings are for secondary education (SLTA), and the degree of Al-Qur'an literacy in primary and secondary education (SD and SMP) has not been explored. This indicates that the extent of Al-Qur'an literacy among children in primary school is unknown. In reality, it is critical to do so in order to determine if kids have the capacity to read and write the Qur'an from an early age or not. This competence is crucial for students to be able to access key religious information sources in order to satisfy the anticipated fundamental competencies (Iswanto et al., 2018).

The awards show that Miftahul Ulum Makarti Jaya Islamic School offers various noteworthy programs at the school, sub-district, and district levels, including:

1) Learning the Qur'an under the term Qur'any Literacy Culture (Brainy-MU) by composing manuscripts and memorizing Juz amma letters using the Al Husna and Protaba methodologies for potential final grade graduates;

2) From 2015 to 2021, the National Examination passing rate was quite acceptable, with a $100 \%$ passing rate;

3) Scouting and dancing arts excellence has the potential to shine at the sub-district and district levels at all times;

4) These amenities and infrastructure include a scientific laboratory, a language laboratory, a computer laboratory, halls, mosques, suitable library rooms, and study rooms that meet building codes;

5) Those who serve as instructors in schools 75 percent are qualified for undergraduate education (S1), 5 percent are still pursuing one level of education, and 20 percent are pursuing a second degree (S2) at PGRI University Palembang (Writer Interview: May 2021);

6) Make literacy writing of the Al-Qur'an Mushaf, write on the "Making" board, news letter, as well as a 6-month program for one book published written by educators, teachers, school principals, and collaborate with students and students in the form of an anthology book, under the shade "Nderes Literasi" (Sukaisih et al., 2021);

7) Prose recitations (learning the Koran), Writing $30 \mathrm{Juz}$ of Al-Qur'an Mushaf in 3 years, and memorizing at least $2 \mathrm{Juz}$ of the Qur'an in 3 years while teaching and learning Al-Qur'an at school; 
8) Once a month, "House of Literacy Pustaka" was held in students' houses, with books borrowed from the school to be read and discussed with the children or the community around the student's home;

9) Hold competitions at the TPA level in the local sub-district on a regular basis as a method of promoting Literacy to Writing Al-Qur'an Mushaf from an early age.

The link with Education Quality Management, which is presently being pushed even more aggressively in light of the pandemic circumstances that show no indications of abating, using online learning (Batubara, 2021), teacher creativity, innovation through hypnoteaching models, teacher professionalism (Maimunah \& Rohiat, 2019), revolutionary 4.0 period learning, historical learning, and learning development are anticipated to be able to carry out their roles for the health of the Indonesian people as a whole despite with limited time and opportunity.

To build a literate generation (educated, literate cultured generation), a long process and suitable and congenial facilities are required, beginning with the home environment, schools, associations, school library facilities or digital literacy libraries, and the environment. employment that facilitate such access Literacy culture, for example, is intimately tied to learning habits and the availability of reading resources in the library in the school setting. Literacy is essentially the core idea of literacy, which is represented in oral reading skills (Rintaningrum, 2019). Literacy is a guideline that fosters human capacities and skills in comprehending values earned through reading and writing (Majid, 2019). Thus, literacy culture is a stage of social activity in particular groups, especially individuals who have grasped the necessity of obtaining information and knowledge, screening, analyzing, and transforming knowledge into a tool for a flourishing existence.

Meanwhile, based on the results of initial observations, management implementation is generally going well, especially during this Covid-19 Pandemic season, it is very widespread in directly accessing information, but if it is associated with the focus of this research, regarding the Role of Education Quality Management in Improving culture Qur'any literacy at the Miftahul Ulum Makarti Jaya Islamic School.

\section{B. Methods}

This study is a social investigation to explore, observe, and comprehend a literacy cultural activity in schools. The purpose of this study is to present an in-depth picture of the school's inventiveness in carrying out literacy culture as the research object. This study employs a qualitative method with descriptive methodologies, (Herdyansah, 2019) Describes qualitative research as a research procedure that generates descriptive data in the form of written or spoken words from people and observable behavior, with the method used emphasizing the process of tracing data until it is felt that it has been used sufficiently to make an interpretation. The subjects of this study were the Principal, Vice Curiculum, Class Guardians, Student Guardians, and class X, XI, and XII students, in accordance with the aim of this study (each class has five students). In this study, data was gathered by observation, interviews, and documentation. Data reduction, data display, and deriving conclusions are some of the data analysis approaches employed in this study.

\section{Results and Discussion}

The Qur'any literacy culture program at the Miftahul Ulum Islamic school went off without a hitch. Before carrying out literacy activities for students, it is preferable to begin by spreading 
a friendly smile, so that in the process of habituation, students are willing to carry out reading and writing Al-Qur'an manuscripts with happy feelings without coercion or punishment for the first 30 minutes every morning. Miftahul Ulum Islamic School avoids punishment because it has a strong influence on the mentality and style of responding to instructors, particularly the school itself. Furthermore, according to doctor Aisyah Dahlan's research, when a kid is screamed at, furious, or punished, it affects the absorption of his brain to science. The brain shrinks as a consequence of the loss of many cells as a result of screaming or punishment.

Identification is the process of identifying and categorizing items or humans based on particular traits. Identification is the process of determining a person's or object's identification. Thus, the teacher is a noble figure whose knowledge and actions have a significant impact on how students learn and work. As a result, the efforts of teachers as educators and other education staff to locate and acknowledge kids who exhibit surplus imagination and creativity are being stepped up so that students as students might become human beings with a Qur'anic literacy culture.

The National Assessment is expected to be a fresh source of optimism for boosting Indonesian students' literacy culture. Indeed, on a global scale, our pupils' literacy skills are concerning. According to the 2018 PISA (Program for International Student Assessment) findings, the reading ability of Indonesian pupils is 371 , ranking 72 out of 78 nations. If reading literacy is low, it is very inevitable that other academic talents in science, social science, and mathematics will be quite low as well. As a result, requiring Indonesian students to be able to apply their reading competences to build individual capacities positively in society would be tough.

The National Assessment is already available at the SMK, SMA/MA, SMP/MTs, and SD levels, and has been implemented at the SD level. The goal of National Assessment is to improve the literacy abilities of Indonesian pupils. The National Assessment will offer a summary of each school's literacy culture's degree of accomplishment. Is it "needs special intervention," "basic," "proficient," or "advanced?" This level position will make it simpler for future consumers of data resulting from National Assessment successes to improve the quality of the Qur'any cultural literacy learning process in schools.

Information on school literacy successes, with a focus on reading and writing abilities, may be gathered from one of the National Assessment instruments, specifically the minimal competency assessment. The cornerstone of the minimal competency assessment is a reading and numeracy literacy assessment. The national examination encourages instructors of all disciplines to focus on building reading competency and logical-systematic thinking by assessing literacy and numeracy.

The questions in the minimal competence exam take the form of higher order thinking skills, which is an adaption of the PISA questions (HOTS). Questions posed by incorporating numerous common concerns mentioned in the description of reading literacy literature. Students in grades 5, 8, and 11 who take the exam must do more than just read. Furthermore, students are expected to grasp, utilize, assess, and reflect on numerous reading difficulties, such as being able to use ideas, methods, facts, and mathematical tools in the exam's numeracy test.

All of these talents are employed to solve the difficulties in the questions that follow the reading of the text. As a result, examinees must be patient and patient when reading and absorbing the material in it so that they can answer questions afterwards. This is not an easy task until you 
Volume 2 (3) 2021

E-ISSN: 2723-6919 P-ISSN: 2746-0827

develop the habit of reading attentively and consistently. Furthermore, most pupils' reading resistance is still relatively low. This statement was reinforced by (Harsiati, 2018) in his essay "Characteristics of Reading Literacy Problems in the PISA Program," published in Litera Journal Volume 17, Number 1, March 2018. According to the paper, the shortcoming of Indonesian youngsters on the PISA test was their low reading endurance. PISA reading questions often feature extended discourses with word counts ranging from 135 to 600 words. As a result, Indonesian children's PISA reading scores are likewise poor.

The Strategic Policy of the National Assessment is aimed to promote students' cultural literacy of the Qur'an. The results of the National Assessment, which will be released in December 2021, can offer an overview of Indonesian students' literacy levels. This will make it easier for users of the National Assessment findings to take strategic initiatives to improve the literacy abilities of the nation's youngsters. Among other things, boosting the quality of learning in religious and public schools.

The Ministry of Education, Culture, Research, and Technology can urge schools and education offices to prioritize enhancing learning quality via reading literacy. Through the learning teacher program and the driving teacher, an innovative teacher figure in teaching topics and the promotion of reading literacy, particularly the ability to produce and publish a book with an ISBN, must be present.

Teachers must always allow pupils to access learning materials from diverse reference books as educators. Then, according to their cognitive and maturity levels, children are urged to learn to increase their vocabulary and build analytical abilities through reading. This is done so that students become accustomed to discussing a variety of books and text types at varying levels of difficulty depending on their requirements. Finally, getting used to books will foster a love of reading and then a love of writing on WhatsApp status, Facebook status, Instagram status, Twitter status, and God willing, what will make you proud is being able to write scientific papers at the end of each graduation as a requirement for taking the final school exam (Darmiati et al, 2020.

Teachers also teach numerous reading skills to their students. Techniques like as picking, skipping, skimming, and scanning are examples. Reading efficiency will improve with the proper reading approach. Children can swiftly summarize the topics of the reading. Even if youngsters only read a few pages of a book, it does not tire them out. This can help youngsters avoid boredom when reading, even if the reading is lengthy. There are also attempts to expand the number of children's reading books. If Kemendikbudristek has printed 120 titles of books and 748 reading materials to promote children's literacy this year, Kemendikbudristek can print 220 titles in 2022, 320 titles in 2023, 420 titles in 2024, and so on. In essence, the number of book titles rose by 100 every year. The books are then given to schools via the Indonesian Post Office program, the Special Allocation Fund, and purchases made with BOSREG funding. Or our schools produce their own reading books using our children's imaginations, and we help them in printing them in specific numbers. Of course, they will have wonderful literacy cultural values, and they can even be sold to the general public.

The school library must be optimized to ensure that there are enough books available. One way is to use the school library as a learning area and resource. This is unquestionably beneficial to pupils. They can broaden their knowledge by visiting the library. In order for the school library to genuinely become a learning instrument, it must contain programs or activities geared 
Volume 2 (3) 2021

E-ISSN: 2723-6919 P-ISSN: 2746-0827

toward knowledge and the growth of students' reading interests. Because increasing reading interest is one sign of a library's success. A librarian is required as a driver to do this. School librarians must be able to communicate with teachers and principals in order to synergize classroom learning with library information sources (Suratman et al, 2020). It is believed that the school library will be able to foster a culture of great reading. According to the findings at the Miftahul Ulum Makarti Jaya Islamic school, kids may create a Literacy Home Library by borrowing a significant number of reading books, a maximum of roughly 20 to 30 volumes to take home once a month, and asking family, relatives, neighbors, or friends to contribute. While reading borrowed books, I was playing. It is intended that this program would foster a stronger reading literacy culture in order to produce a religious young generation that is religious to the country, religious to the globe, and religious in the hereafter.

We open a doorway to the world via reading, and we fly together to fulfill Indonesia's goals of moving forward and moving together. Hopefully, the National Assessment and the collaborative efforts of all parties in developing students' literacy culture will yield fruit, and our country will become a literacy culture in the future. The National Assessment is changing the culture of Qur'any literacy.

The Miftahul Ulum Islamic school evaluates by holding regular monthly meetings to see, select, and determine who deserves a prestigious award, such as that achieved by teacher Sabarudin as principal at SMAN 1 Manggar from Bangka Belitung in winning two awards in the field of literacy at the same time. The prize was granted by the West Java Writers Teaching Community. Parasamya Suratma Nugraha 2021 and Parasamya Susastra Nugraha 2021 are the titles of the prizes.

The principal, as a policymaker, must have a clear and defined vision and mission while developing or designing a program. The role of education quality management in improving the culture of qur'any literacy at Miftahul Ulum Makarti Jaya Islamic School as an effort to produce an output generation that is superior in innovative, critical, leadership, and creative superior and able to compete well and have more value in religious abilities, it is necessary to develop Skills. Being cultural and literate, as well as critical thinking, are two qualities that can develop outputs that are ready to participate in society. Language literacy refers to a person's capacity to read, write, talk, and listen in order to accomplish a certain purpose. The capacity to read and write is utilized in relation to word issues. The capacity to grasp the meaning of a collection of letters and written words is referred to as reading ability. While writing skill is the capacity to explain what is known and what has to be transmitted in written form. When students read problem words, comprehend them, and then construct mathematical models, they employ language literacy, or the ability to read and write (Fatmanissa \& Sagara, 2017).

Literacy is a creative capital that may be used in a variety of ways to create and improve. In their attempts to develop a school literacy culture, schools use a variety of approaches and tactics to achieve their goals. The research findings demonstrate numerous things in developing a culture of Qur'any literacy in schools, which may be defined by the following analytical study, which involves planning, organizing, executing, and overseeing cultured Qur'any literacy in the Islamic school Miftahul Ulum Makarti Jaya (Pangeran et al., 2010) (Mahendrartha et al, 2020). 


\section{Conclusion}

Based on the findings of a study that focused on the role of education quality management in strengthening the culture of qur'any literacy at the Miftahul Ulum Makarti Jaya Islamic school, with the subfocus of planning, organizing, implementing, and monitoring how things were going. The role of education quality management in improving the culture of qur'any literacy at Miftahul Ulum Makarti Jaya Islamic School as an effort to produce an output generation that is superior in innovative, critical, leadership, and creative superior and able to compete well and have more value in religious abilities, it is necessary to develop Skills. Being cultural and literate, as well as critical thinking, are two qualities that can develop outputs that are ready to participate in society.

\section{E. Acknowledgement}

We thank to the principal of Sekolah Islam Miftahul Ulum Makarti Jaya, Rector Universitas PGRI Palembang, and friends of graduate program educational management Universitas PGRI Palembang who have supported us to do this project.

\section{References}

Batubara, M. A. N. (2021). Inovasi Manajemen Pembelajaran Dalam Meningkatkan Kualitas Pendidikan Islam Bagi Siswa [Learning Management Innovation in Improving the Quality of Islamic Education for Students]. 3.

Darmiati, D., Kristiawan, M., \& Rohana, R. (2020). The Influence of School Leadership and Work Motivation toward Teacher's Discipline. Journal of Social Work and Science Education, 1(1), 32-44. https://doi.org/10.52690/jswse.v1i1.8

Fadhli, M. (2020). Penerapan Strategi Literature Circle secara Daring dalam Meningkatkan Literasi Membaca Peserta Didik [Application of the Online Literature Circle Strategy in Improving Students' Reading Literacy]. In Seminar Nasional Pendidikan Bahasa dan Sastra (pp. 106-118).

Fahmi, M., Atmazaki, \& Manaf, N.A (2014). Peningkatan Keterampilan Menulis Narasi melalui Model Pembelajaran Langsung Siswa Kelas VII SMP 26 Sirolangun [Improving Narrative Writing Skills through Direct Learning Model for Class VII Students of SMP 26 Sirolangun]. Jurnal Bahasa, Sastra dan Pembelajaran, 2(3) 70-80.

Fatmanissa, N., \& Sagara, R. (2017). Language Literacy and Mathematics Competence Effect Toward Word Problems Solving. Infinity Journal, 6(2), 195. https://doi.org/10.22460/infinity.v6i2.p195-206

Fitriani, Y. (2018). Pengaruh Minat Membaca Dan Penguasaan Kosakata Terhadap Kemampuan Menulis Cerpen Kelas VI SD Negeri 68 Palembang [The Influence of Reading Interest and Vocabulary Mastery on the Ability to Write Short Stories for Class VI SD Negeri 68 Palembang]. Jurnal Pembahsi (Pembelajaran Bahasa Dan Sastra Indonesia), 8(2), 32. https://doi.org/10.31851/pembahsi.v8i2.2082

Harsiati, T. (2018). Karakteristik Soal Literasi Membaca Pada Program Pisa [Characteristics 
of Reading Literacy Questions in the Pisa Program]. Litera, 17(1), 90-106. https://doi.org/10.21831/ltr.v17i1.19048

Herdyansah, H. (2019). Metode Penelitian Kualitatif untuk Ilmu-Ilmu Sosial: Perspektif Konvensional dan Kontemporer [Qualitative Research Methods for the Social Sciences: Conventional and Contemporary Perspectives].

Iswanto, A., Oetomo, S. B., Noviani, N. L., Khalim, S., Atmanto, N. E., \& Rachmadani, A. (2018). Literasi Al-Quran Siswa SMP di Jawa Timur [Al-Quran Literacy for Middle School Students in East Java]. Suhuf, 11(1), 1-28. https://doi.org/10.22548/shf.v11i1.306

Laksono, T. A. (2021). Isyarat-isyarat Manajemen Mutu Pendidikan [Educational Quality Management Cues]. Southeast Asian Journal of Islamic Education Management, 2(1), $15-28$.

Mahendrartha, A., Tobari, T., \& Tabula, R. V. (2020). Adiwiyata-Based School Management in Indonesia. Journal of Social Work and Science Education, 1(1), 1-7. https://doi.org/10.52690/jswse.v1i1.4

Maimunah \& Rohiat. (2019). Hubungan Antara Supervisi Klinis, Kompetensi Pedagogik Guru Dengan Kinerja Guru [The Relationship Between Clinical Supervision, Teacher Pedagogic Competence and Teacher Performance]. Jurnal Ilmiah Manajemen Pendidikan Program Pascasarjana, 13(2), 137.

Majid, Z. A. (2019). Refleksi Al-Quran Dalam Literasi Global [Reflection of the Quran in Global Literacy]. Al Marhalah, 3(2), 81-90.

Pangeran, S., Kusuma, D., Barat, S. I., No, H. A., Kidul, S., \& Indramayu, J. (2010). Manajemen Mutu Perguruan Tinggi Agama Islam Swasta Bunyamin Alamsyah [Bunyamin Alamsyah Private Islamic Higher Education Quality Management].

Rintaningrum, R. (2019). Literacy: Its Importence and Changes in the Concep and Definition. TEFLIN Journal, 20(January).

Sukaisih, T., Islam, S., Ulum, M., Jaya, M., \& Selatan, B. S. (2021). Inspirasi Nderes Literasi dalam Gerakan Abadikan Kenangan dalam Tulisan [Bunyamin Alamsyah Private Islamic Higher Education Quality Management]. 1(3), 226-232.

Suratman, S., Arafat, Y., \& Eddy, S. (2020). The Influence of Principal's Leadership and Teacher's Competence toward Teacher's Performance in Indonesia. Journal of Social Work and Science Education, 1(2), 96-104. https://doi.org/10.52690/jswse.v1i2.32

Syarifuddin, U. H., Munir, M. (2021). Implementasi Literasi Al-Qur'an dalam Pembinaan Karakter Religiusitas Peserta Didik pada SMA/SMK di Kabupaten Sidenreng Rappang [Implementation of Al-Qur'an Literacy in the Religious Character Development of Students at SMA/SMK in Sidenreng Rappang Regency]. In Jurnal Pendidikan Agama

Zein, A., Mardianto, M., \& Ariefky, H. (2021). Program Literasi Al Quran Di Sekolah (Studi Kasus di SD Islam Al-Amjad Kota Medan) [Al-Quran Literacy Program in Schools (Case 
Journal of Social Work and Science Education

Volume 2 (3) 2021

E-ISSN: 2723-6919 P-ISSN: 2746-0827

Study at Al-Amjad Islamic Elementary School, Medan City)] (Vol. 05, Issue September, pp. 224-241). 